\title{
CHANGES IN ASTIGMATISM BEFORE AND AFTER PTERYGIUM SURGERY
}

\author{
Parajuli $R^{1^{*}}$ Bajracharya $L^{2}$
}

\section{Affiliation}

1. Pediatric Ophthalmologist, Department of Pediatric Ophthalmology, Tilganga Institute of Ophthalmology

2. Associate Professor, Department of Cornea, Tilganga Institute of Ophthalmology, Kathmandu, Nepal

\section{ARTICLE INFO}

\section{Article History}

\begin{tabular}{|c|c|}
\hline Received & 30 October, 201 \\
\hline Accepted & 21 April, 2019 \\
\hline Published & 30 April, 2019 \\
\hline
\end{tabular}

(c) Authors retain copyright and grant the journal right of first publication with the work simultaneously licensed under Creative Commons Attribution License CC - BY 4.0 that allows others to share the work with an acknowledgment of the work's authorship and initial publication in this journal.

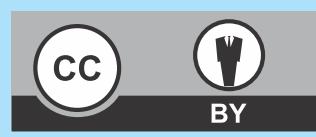

\section{ORA 97}

\section{DOI: http://dx.doi.org/10.3126/bjhs.v4i1.23929}

\author{
* Corresponding Author \\ Dr. Rojeeta Parajuli \\ Pediatric Ophthalmologist / Pediatric Ophthalmology \\ Tilganga Institute of Ophthalmology \\ Kathmandu, Nepal \\ Email:dr.rojita@gmail.com \\ ORCID ID: https://orcid.org/0000-0002-5735-0816
}

\section{Citation}

Parajuli R, Bajracharya L. Knowledge and Awareness of Basic Life Support among Medical Staffs of Birat Medical College and Teaching Hospital. BJHS 2019;4(1)8:596-601.

\begin{abstract}
\section{Introduction}

Pterygium is a degenerative condition of the subconjuctival tissue, which proliferates as vascularised granulation tissue to invade the cornea resulting in destruction of the superficial layer of the corneal stroma and bowman's membrane. This change in cornea leads to corneal opacity, visual impairment and significant induced astigmatism. The ensuing pathologic changes consist of elastoid degeneration of collagen and the appearance of subepithelial fibrovascular tissue
\end{abstract}

\section{Objective}

To measure the change in corneal astigmatism after pterygium surgery and the relationship of astigmatism with respect to size of pterygium.

\section{Methodology}

Hospital based prospective, non-randomized study, comprising 61 eyes of 56 patients who underwent pterygium excision and autologus conjuctival graft during the period October 2009 to September 2010. A total of 56 participants were enrolled and followed upto 3 months after surgery. Corneal topography was used to measure corneal astigmatism before and after pterygium surgery.

\section{Results}

The mean age of patient was 46.11 years, standard deviation was 18.86 Male: female ratio: 0.8:1

Preexisting induced astigmatism among study group patients was 2.6D and mean astigmatism after pterygium surgery was $0.8 \mathrm{D}$. This finding was found to be statistically significant( $P$ value $<0.001)$. Over all change in mean astigmatism was 1D in our study. In grade I Mean astigmatism before surgery was $0.96 \mathrm{D}$ and Mean astigmatism after surgery was $0.46 \mathrm{D}$, Changes in mean astigmatism after surgery was $0.50 \mathrm{D}$. In grade II Mean astigmatism before surgery was $1.99 \mathrm{D}$ and Mean astigmatism after surgery was 0.54D, Changes in mean astigmatism after surgery was $1.45 \mathrm{D}$. In grade III Mean astigmatism before surgery was 10.71D and Mean astigmatism after surgery was 3.10D, Changes in mean astigmatism after surgery was 7.61D. The change in mean astigmatism is greatest in patients with grade III pterygium.

\section{Conclusion}

After pterygium surgery astigmatism significantly reduces and astigmatism increases with the grade of pterygium.

\section{KEY WORDS}

Primary pterygium, astigmatism, autologus conjuctival graft, grading of pterygium. 


\section{INTRODUCTION}

Pterygium is a degenerative condition of the subconjuctival tissue, which proliferates as vascularised granulation tissue to invade the cornea, destroying the superficial layer of the stroma and bowman's membrane, the whole being covered by conjuctival epithelium.

The occurrence of pterygia is strongly correlated with Ultraviolet-exposure, although dryness, inflammation and exposure to wind, dust or other irritants. Ultraviolet B is mutagenic for the $p 53$ tumor suppresor gene in limbal basal stem cells. Over expression of cytokines such as transforming growth factor beta (TGF- $ß$ ) and vascular endothelial growth factor leads to collagenase up-regulation, cellular migration and angiogenesis.

The ensuing pathologic changes consist of elastoid degeneration of collagen and the apperance of subepithelial fibrovascular tissue.

The cornea shows destruction of Bowman's layer of fibrovascular ingrowth, frequently with mild inflammatory changes. The epithelium may be normal, thick or thin and occassionaly shows feaures of dysplasia. The lesion appears as a triangular encroachment of the conjuctiva upon the cornea with numerous small opacities lying deeply in the neighbouring part of cornea in front of its blunt apex.

Pterygia are nearly always preceded and accompanied by pinguecula and when single, is usually on nasal side, when double the temporal lesion develops later. In the early stages it is thick and vascular, becomes thin and pale when it ceases to grow but never disappear. When it ceases to progress, consolidation occurs with formation of dense fibrous tissue and the development of considerable corneal astigmatism. ${ }^{1}$

Regular and irregular astigmatism occurs in proportion to pterygium size ${ }^{2}$. Ordinarily the condition is symptomless, but vision becomes impaired if it progresses into the pupillary area of the cornea ${ }^{1}$

A pigment iron line (Stocker's line) may be seen in advance of a pterygium on the cornea. ${ }^{2}$

The removal of pterygium is indicated if there is large pterygium that is about to cover the papillary area over the cornea, causes intense discomfort, foreign body sensation, redness.

A pterygium-induced refractive change often leads to visual impairment. These changes are localized and cannot be measured accurately either by refraction or keratometry. During manifest refraction patient deals with two images, one from the more spherical temporal cornea and one from the flatter nasal cornea. The patient preferentially views the more spherical image and therefore the corneal changes are incompletely reflected in the refraction. . $^{3,15,16,17}$

Keratometry measures only the central cornea and peripheral cornea is ignored and hence the results can be erroneous in eyes with pterygium.

Pterygium was seen to have a considerable effect on topographic indices in the present series. Flattening was seen in the horizontal meridian, which was associated with astigmatism. The exact mechanism of flattening is not clear. It is thought to be caused by the formation of tear meniscus between the corneal apex and the elevated pterygium, causing an apparent flattening of the normal corneal curvature. $^{4}$

More common surgical technique that is accepted worldwide now is excision of the pterygium combined with autologous conjunctival grafting from same eye because other surgical techniques are associated with either high recurrence rate or more complications.

In 1980, Dr. José I. Barraquer ${ }^{13}$ reported the first use of a free conjunctival autograft in pterygium surgery, a technique later popularized by Kenyon and Tseng. ${ }^{14}$

Our study aim to study correlation between size of pterygium and induced astigmatism and also difference in preexisting induced astigmatism to astigmatism after surgery.

\section{METHODOLOGY}

Patient presenting to out patient department of Tilganga Institute of Ophthalmology with primary ptreygium requiring surgical management from October 2009 to September 2010 were included for the study purpose. Double pterygium, pterygium with corneal disease that can affect the corneal astigmatism(e.g. corneal scar), pseudopterygium, recurrent pterygium were excluded. Written consent were taken from all patients. A total of 56 participants (61 eyes) were enrolled. All patients underwent pterygium excision with autologus conjuctival graft from superotemporal bulbar conjunctiva and follow up schedule was prepared as day 2,1week, 1 month and 3months after surgery. Data were collected with respect to demographics, data entry and analysis was performed using computer software SPSS 11.5 version. Statistical analysis was measured using student $t$ test and $P$ value $<0.05$ was considered significant.

\section{Preoperative Evaluation}

Diagnosis of pterygium was made based on presence of triangular fibrovascular growth with apex encroaching towards the cornea using a slit lamp bimicroscope. Demographic profiles of the patients were filled in detail, Examination included visual acquity assessment including detail slit lamp examination including site, size of pterygia, of pterygia (Horizontal), presence or absence of dellen. Dimensions were measured from the limbus using a caliber in slit lamp in millimeters $(\mathrm{mm})$. Apex of pterygium from the limbus towards the tip of pterygium and base of pterygium covering the limbus were measured. During slit-lamp examination slit beam was focused on the nasal limbus, pterygium were graded depending on the extent of corneal involvement:'Sejal Maheshwari, MS, 2007) : $:^{3,15,16,17}$

Grade I - between limbus and a point midway between limbus and pupillary margin.

Grade II- head of the pterygium present between a point midway between limbus and pupillary margin and pupillary margin (nasal pupillary margin in case of nasal pterygium and temporal margin in case of temporal pterygium) Grade III-crossing pupillary margin. 
Indications for the need of surgery were noted as Symptomatic pterygium: chronic eye irritation in the affected eye on and off at least for 3 times a year or less, vision threatening pterygium which was very close to the pupillary border and for cosmetic purpose. Astigmatism were measured by an experienced optometrist by performing corneal topography examination before and after surgery (on four weeks and on 3 months), by corneal topography machine. (Topcon)

\section{Interventions}

\section{Operative Procedure, Post Operative Care and Follow Up}

Surgery was performed under retrobulbar block, All patients received a drop of topical $4 \%$ Xylocaine (Astrazeneca Pharma India limited, Banglore) \& injection of retrobulbar block with 3ml-2\%Xylocaine/ Epinephrine 1:80000 + 1.5ml - 0.5\% Bupivacaine (Astrazeneca Pharma India limited, Banglore) a total of $4.5 \mathrm{ml}$ anesthetic agent using a $5 \mathrm{cc}$ disposable syringe (Terumo Corporation. Tokyo, Japan). After retro bulbar block patients eye was pressure padded for 3-5 minutes then transfered to the operating table as ocular anaesthesia was confirmed. Pterygium was excised using a plain forceps \& after meticulous excision of tenon, conjunctival defects was closed using the autologous conjunctiva graft taken from the superior/superiotemporal bulbar conjunctiva. Minimal cautery was applied to the host area. Graft was prepared using plain forceps, sutured using Vicryl 8-0, then eye was padded with ointment \& tapped. After removal of the pad all patient received post operative medications i.e. topical drops combination of Chloramphenicol (1\%) and Dexamethasone 0.1\% (Pyrimon) four times a day from next day of surgery with Chloramphenicol eye ointment $0.3 \%$ at bed time for first one week of surgery and gradually tapered over a period of month.

Patients were closely observed, day 2, 1 week, 1 month, 3 month after surgery and intraoperative complications were documented as damage to the medial rectus, dog hole in the graft, small graft and damage to adjacent ocular structures. On each follow up visual acuity, retinoscopic examination, subjective refraction was taken and corneal topographic examination was done on 1 month and 3 months.

\section{RESULTS}

The mean age of patient was 46.11 years, standard deviation was 18.86 Male: female ratio: $0.8: 187.5 \%$ patients were from hilly region, $8.9 \%$ were from Tarai region, $3.6 \%$ were from mountain region.

Graph 1: Showing astigmatism before surgery, after one and 3 months, astigmatism had significantly reduced 3 months after surgrey

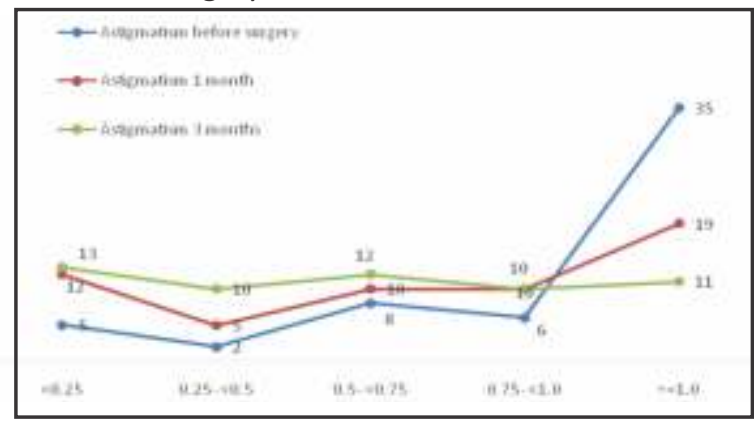

Table: 1: Indication of pterygium surgery
\begin{tabular}{|l|c|c|}
\hline Complaints of patient & $\begin{array}{c}\text { No. of } \\
\text { patients }\end{array}$ & Percentage \\
\hline Foreign Body Sensation & 40 & $71.43 \%$ \\
\hline Cosmesis & 6 & $10.71 \%$ \\
\hline Decrease vision & 6 & $10.71 \%$ \\
\hline $\begin{array}{l}\text { Others like ocular } \\
\text { discomfort,redness }\end{array}$ & 4 & $7.14 \%$ \\
\hline Total & 56 & $100.00 \%$ \\
\hline
\end{tabular}

Here, commonest symptoms of pterygium is Foreign Body sensation, which was complained by $71.43 \%$

Table 2: Comparison of preoperative vision and postoperative vision after $4 \mathrm{wks}$

\begin{tabular}{|c|c|c|}
\hline Vision & preoperative & Post operative(4wks) \\
\hline Change & 0 & 0 \\
\hline Unchanged & 56 & 56 \\
\hline Total & 56 & 56 \\
\hline
\end{tabular}

There was no change in visual acuity before and one month after surgery.

Table 3: Comparison of preoperative vision and postoperative vision after 3 months

\begin{tabular}{|l|c|c|}
\hline Vision & preoperative & $\begin{array}{c}\text { Post operative } \\
\text { (3 months) }\end{array}$ \\
\hline Change & 0 & 0 \\
\hline Unchanged & 56 & 56 \\
\hline Total & 56 & 56 \\
\hline
\end{tabular}

There was no change in visual acuity before and three month after surgery

Table 4: Correlation of Astigmatigm with Pterygium Size
(Before and After Surgery)
\begin{tabular}{|c|l|c|c|c|c|c|}
\hline Grade & Astigmatism & Mean & SD & Minimum & Maximum & Count \\
\hline \multirow{3}{*}{1} & Before surgery & .96 & 1.31 & 0.00 & 5.00 & 13 \\
& After 1 month & .55 & .36 & .12 & 1.12 & 13 \\
& After 3 months & .46 & .37 & 0.00 & 1.25 & 13 \\
\hline \multirow{3}{*}{2} & Before surgery & 2.17 & 2.53 & .12 & 10.13 & 37 \\
& After 1 month & .73 & .61 & 0.00 & 2.50 & 37 \\
& After 3 months & .51 & .38 & 0.00 & 1.13 & 37 \\
\hline \multirow{3}{*}{3} & Before surgery & 10.71 & 5.16 & 6.38 & 20.25 & 6 \\
& After 1 month & 4.80 & 5.62 & 1.25 & 16.00 & 6 \\
& After 3 months & 3.08 & 3.53 & .50 & 10.00 & 6 \\
\hline
\end{tabular}

Preoperatively, when the grading of Pterygium increases astigmatism also gradually increases and postoperatively after surgery astigmatism has been reduced.

Table 5: Comparison of mean astigmatism before and after surgery

\begin{tabular}{|l|c|c|c|}
\hline & $\begin{array}{l}\text { Astigmatism before } \\
\text { surgery }(\mathbf{n}=56)\end{array}$ & $\begin{array}{l}\text { Astigmatism } \\
\mathbf{3} \text { months }(\mathbf{n}=56)\end{array}$ & p value \\
\hline Mean/ SD & $2.8(3.9)$ & $0.8(1.4)$ & $<0.001$ \\
\hline
\end{tabular}

Table 6: Comparison of mean astigmatism one months and three months after surgery

\begin{tabular}{|l|c|c|c|}
\hline & $\begin{array}{c}\text { Astigmatism } \\
1 \text { month }\end{array}$ & $\begin{array}{c}\text { Astigmatism } \\
3 \text { month }\end{array}$ & p value \\
\hline Mean & 1.1 & 0.8 & \multirow{2}{*}{0.11} \\
\hline Std. Deviation & 2.2 & 1.4 & \\
\hline
\end{tabular}


Table 7: Comparison of Astigmatism before surgery and after 1 month

\begin{tabular}{|l|c|c|c|}
\hline & $\begin{array}{c}\text { Astigmatism } \\
\text { before surgery }\end{array}$ & $\begin{array}{c}\text { Astigmatism } \\
1 \text { month }\end{array}$ & p value \\
\hline Mean & 2.8 & 1.1 & \multirow{2}{*}{$<0.001$} \\
\hline Std. Deviation & 3.9 & 2.2 & \\
\hline
\end{tabular}

\section{DISCUSSION}

Majority of the time pterygium is symptomless, but vision becomes impaired if it progress to the pupillary area of the cornea. ${ }^{1}$ Regular and irregular astigmatism occurs in proportion to pterygium size ${ }^{2}$ Pterygium was seen to have a considerable effect on topographic indices in the present series. Flattening was seen in the horizontal meridian, which was associated with astigmatism. The exact mechanism of flattening is not clear. It is thought to be caused by the formation of tear meniscus between the corneal apex and the elevated pterygium, causing an apparent flattening of the normal corneal curvature. ${ }^{4}$ Pterygium is common in increasing age ${ }^{5}$ This study observed ptergium was common in age groups of 31-40 years and in above 50 years.

The peak seen in 31-40 years group may be because in these group patients are aesthetically more concerned so they visit ophthalmologist more frequently. The other reason may be because in these groups pterygium is in aggressive form and they are more symptomatic and they visit hospital more frequently.

The mean age of the patients were $56 \pm 5$ years in a study done by Juan Cano-Parra et al $^{6}$

In our study pterygium was more common in females $(53.6 \%)$ which is similar to study done by Shu Fang, RongKung Tsai et al. ${ }^{8}$ This may be due to the fact that most of the female patients were from Kathmandu valley, who were aesthetically more concerned and visited hospital for treatment. However the similar study done by Seitz B et al where the pterygium was more common in male.

In geographical distribution out of 56 patient, 49(87.5\%) were from Hilly region, $5(8.9 \%)$ from Terai region and $2(3.6 \%)$ were from mountain region. In this study most of the patients enrolled were from Hilly region because of feasibility to come for follow up.

In our study all the pterygium were nasal. Since Nepal is an agricultural country, there is exposure to sunlight which is a leading cause of pterygium. When the eye is exposed to sunlight the sunlight directly reflected from nasal bridge of nose to the nasal part of the conjunctiva, which leads to formation of nasal pterygium.

A study done in Taiwan by Shu-Fang et al (2006) also shows the high incidence of nasal Pterygium. And they concluded that the high prevalence of pterygium (53.01\%) among the middle-aged and elderly population of the Tao tribe in Orchid Island may be related to the latitude, ultraviolet exposure and lifestyle. ${ }^{8}$

In this study $40(71.43 \%)$ of patients presented with foreign body sensation, 6(10.71\%) with decreased vision and
$6(10.71 \%)$ aesthetic concern and $4(7.14 \%)$ presented with other complaints like redness, ocular discomfort.

In our study the mean astigmatism reduced from $2.8 \mathrm{D}$ to $0.80 \mathrm{D}$, and the change in mean astigmatism was $1.9 \mathrm{D}, \mathrm{P}$ value is 0.001 .

In the current study all the topographic parameters were seen to improve significantly following pterygium excision.

Lin and Stern G et al ${ }^{9}$ (1998), Sejal Maheshwari, ${ }^{3}$ ( 2007), Errais K, Bouden J, Mili-Boussen I, Anane R, et al ${ }^{10}$ (2008), Ashaye AO, Avisar R, Loya $N$ et $a l^{11}(2000)$ shows astigmatism tends to increase with the increasing size of the lesion. Topographic astigmatism tends to be improved by successful removal of the pterygium. These findings suggest that early surgical intervention in the pterygium may be indicated when the lesion shows that Grade II or larger pterygium was associated with increase in astigmatism, asymmetry and irregularity. Hence, for patients with pterygium requiring cataract surgery, decision of surgery should be taken depending on the grade of pterygium; in cases with Grade I, atrophic and non-progressive pterygium one can consider cataract surgery directly. However, pterygium Grade II or larger significantly affects the refractive component of cornea which can lead to erroneous intraocular lens power calculation and post-cataract refractive surprise, pterygium excision should be performed prior to cataract surgery, cornea stabilize one month after pterygium surgery. Hence, cataract surgery or refractive surgery if considered should be performed at least one month after pterygium surgery. ${ }^{12}$

\section{CONCLUSION}

Astigmatism increases with the grade of pterygium. Astigmatism significantly reduces after pterygium surgery.

\section{RECOMMENDATIONS}

Proper adjustment of the glass will be needed after patient undergoes pterygium surgery and patient also needs counseling about the change in his refractive error. So, Pterygium Surgery is recommended when there is significant astigmatism ( usually grade II Pterygium) and also it should be done before the cataract surgery because it leads to proper intraocular lens calculation.

\section{LIMITATION OF THE STUDY}

Small sample size

\section{ACKNOWLEDGEMENTS}

None

\section{CONFLICT OF INTEREST}

None

\section{FINANCIALDISCLOSURE}

None 
Picture 1 : Grade I Pterygium

Picture 2: Grade II Pterygium
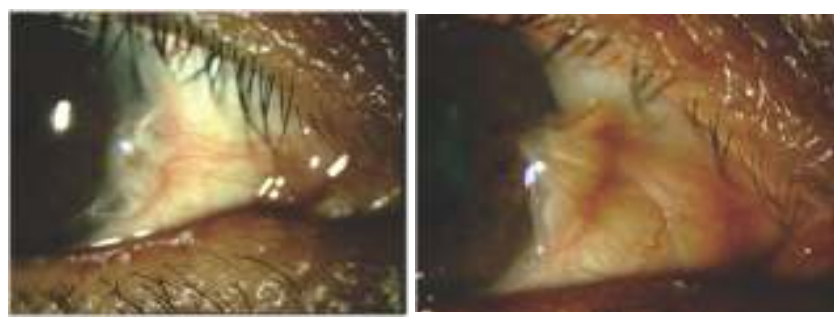

Picture 3: Grade III Pterygium

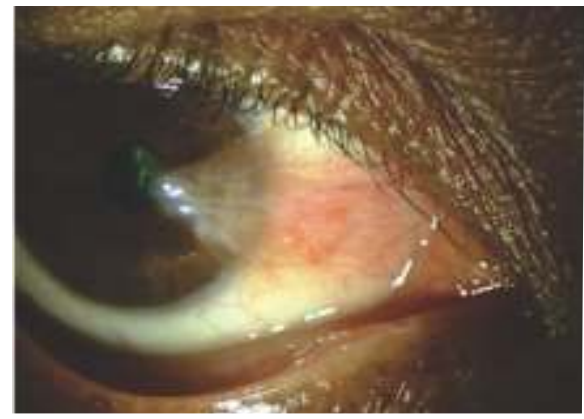

Picture 4: Pterygium is excised from its site

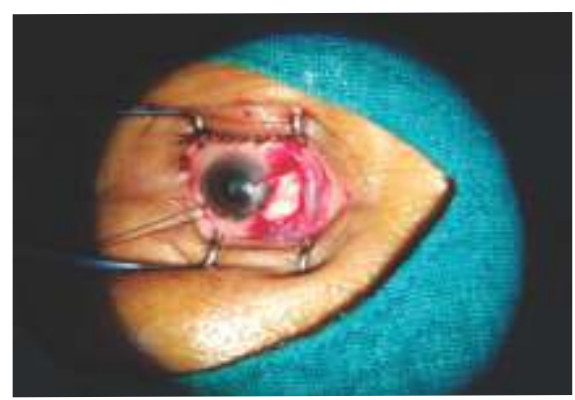

Picture 5: Autologus conjuctival graft is secured with 8.0 vicryl suture

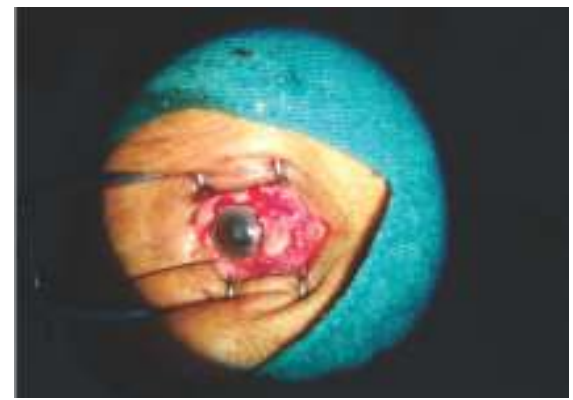

Picture 6: $1^{\text {st }}$ post-operative day, graft in situ and sutures are intact

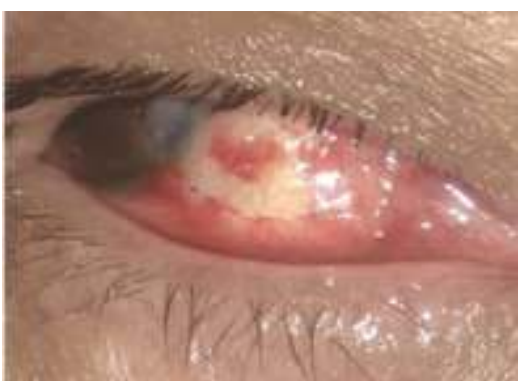

Picture 7: 3 month post-operative day

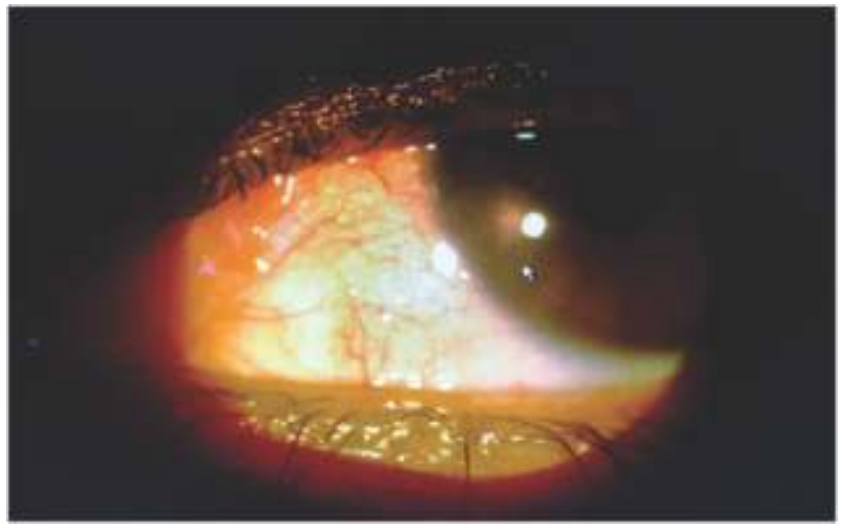

Picture 7: Corneal topography showing preoperative astigmatism
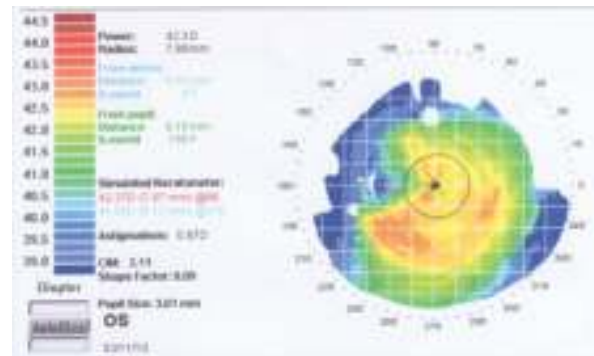

Picture 8: Corneal Topography of same patient 3 months after pterygium surgery
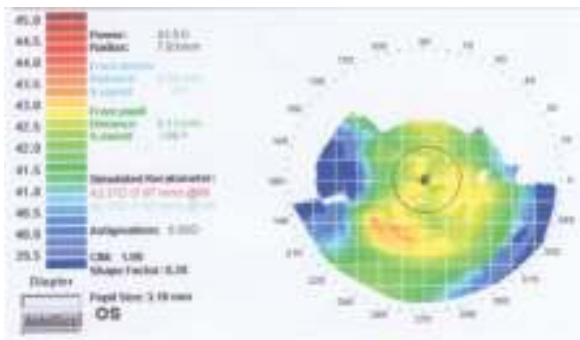

Picture 9: Corneal topography showing preoperative astigmatism

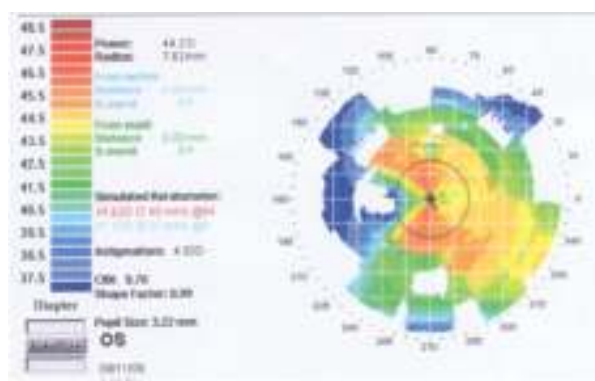

Picture 10: Corneal Topography of same patient 3months after pterygium surgery.
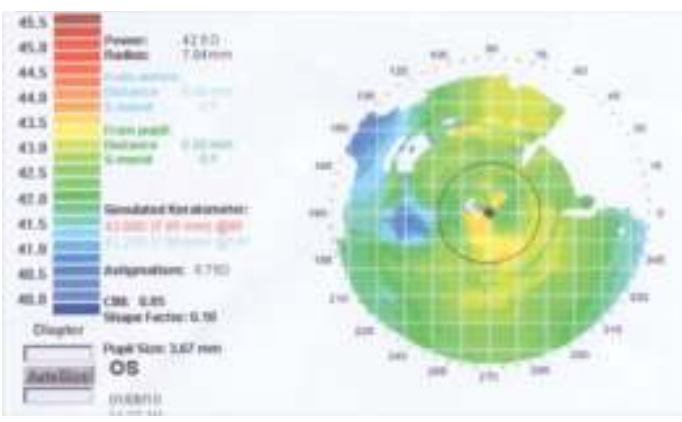


\section{REFERENCES}

1. Ramanjit Sihota,Radikha Tandon.Parson's Disease of the eye, Elsevier, (2007) Twentieth edition,: page no.175-176.

2. John E.Sutphin, Jr.MD et al, Clinical approach to depositions and degenerations of the conjunctiva, Cornea and Sclera, American Academy of Ophthalmology San Francisco, (2008-09) CA 9412207424, page no.366

3. Sejal Maheshwari, MS, Pterygium-induced corneal refractive changes, Indian J Ophthalmology 2007, 55:383-6 ; DOI: 10.4103/ 0301-4738.33829

4. Oldenburg JB, Garbus J, McDonnell JM et al conjunctival pterygia. Mechanism of corneal topographic changes,Cornea 1990; 9:200-4; PMID: 2373014 .

5. Ashaye $\mathrm{AO}$, Refractive astigmatism and pterygium, Afr J Med, MedSci.1990 Sep; 19(3): 225-8; PMID : 12518915

6. Juan Cano-Parra, Inmaculada Bueno-Gimeno et al, Astigmatism variations in pterygium surgery, Annals of Opthalmology J, volume 34, Number 1/March, 2002,23-25; https://doi.org/10.1007/s12009 $-002-0053-1$

7. Seitz B, Gutay A, Kuchle M, Kus MM, Langenbucher A at el Impact of pterygium size on corneal topography and visual acuity - a prospective clinical cross-sectional study, Klin Monatsbl Augenheilkd 2001, 218: 609-15; DOI:10.1055/s-2001-17639

8. Shu-Fang, Rong-Kung,Tsai, I-Cheng. Epidemiology of pterygium among middle aged and elderly aborigines of the Tao tribe of Orchid Island, Taiwan.Tzu Chi Med J 2006,18 No. 4; 18:283-286
9. Lin A, Stern G, Correlation between pterygium size and induced corneal astigmatism, cornea $1998 \mathrm{Jan}$; 17(1): 28-30.PMID:9436877

10. Errais K, Bouden J, Mili-Boussen I, Anane R, Beltaif O, Meddeb Ouertani, A. Effect of pterygium surgery on corneal topography, Eur J Ophthalmol, 2008 Mar-Apr; 18(2): 177-8113;PMID:18320508

11. Avisar R, Loya N, Yassur Y, Weinberger D, pterygium-induced corneal astigmatism, Isr Med Assoc J. 2000 Jan;2(1):14-5.PMID:10892364

12. A Tomidokoro; K Miyata, Y Sakaguchi; T Samejima, at el on effects of pterygium on corneal spherical power and astigmatism. Ophthalmology Volume: 107 2000 Aug;107:1568-7: PMID:10919910

13. Barraquer JI, Binder PS, Buxton JN, et al. Etiology and treatment of the pterygium, In: Symposium on Medical and Surgical Diseases of the Cornea, Transactions of the New Orleans Academy of Ophthalmology, St Louis: CV Mosby; 1980:167-178.

14. Kenyon KR, Tseng SCG, Limbal autograft transplantation for ocular surface disorders, Ophthalmology, 1989; 96:709-723.

15. Maheshwari S. Effect of pterygium excision on pterygium-induced astigmatism. Indian J Ophthalmol 2003;51:187-8.

16. Yagmar M, Altan A, Ozcan MD, Sari S, Ersoz RT. Visual acuity and corneal topographic changes related with pterygium surgery. J Refract Surg 2005;21:166-70

17. Cinal A, Yasar T, Demirok A, Topuz H. The effect of pterygium surgery on corneal topography. Ophthalmic Surg Lasers 2001;32:35-40. 